\title{
An Exploratory Study of Factors Affecting Production Function in the Accounting Industry
}

\author{
Seok-Young Lee \\ Professor, Department of Management, Sungshin Women's University, South Korea \\ sylee@sungshin.ac.kr
}

\begin{abstract}
Using a hand-collected unbalanced panel of data for Korean accounting firms from the year 1997 to 2018, this paper analyzes the production function relating the output of accounting firms as a function of two labor inputs and a capital input along with contextual variables that influence the relationship between the three inputs and the single output. The major results from the empirical analysis of this study are drawn as follows. First, this study finds that both the economies of scale and the economies of scope exist in the Korean accounting industry over the 1997-2018 period. Second, it is documented that the level of productivity improves continuously over the sample period. Third, it is shown that both the proportion of revenue from taxation services and the proportion of revenue from management advisory \& other services are productive in generating total revenue, while the proportion of revenue from auditing services is not productive. In addition, taxation services are found to exhibit a higher productivity than management advisory \& other services. Lastly, it is demonstrated that the contextual variables such as the degree of leveraging of partner time, the level of investment in employee training and education, the employee retention rate, the debt-to-equity, and the quick ratio are positively associated with accounting firm productivity.
\end{abstract}

Keywords: Production function, Economies of scale, economies of scope, productivity, Accounting industry, Accounting firm

\section{Introduction}

For the past few decades, a lot of emphasis and effort has been placed on how to improve productivity in organizations. This productivity improvement in this rapidly changing economic environment can lead firms to sustain their competitiveness and firm value. The key research question raised in this study is what are the major firm characteristics that affect the productivity in organizations belonging to a certain industry and the industry itself, such as accounting firms and the accounting services industry. To address this research question, this study examines the production function relating the output of accounting firms as a function of its input resources such as labor and capital, along with contextual variables that influence the relationship between the output variable and the input resources variables [1][2][3]. Total operating revenue is considered as the single output variable in this study. As input resource variables for labor, the following two separate groups of human resources are considered: (i) the number of professionals and (ii) the number of supporting personnel [2][3]. As another

Article history:

Received (April 4, 2021), Review Result (May 9, 2021), Accepted (July 18, 2021) 
input resource variable for capital, this paper considers the book value of noncurrent assets that represent a capital investment at the firm level [4].

To reflect the differences in the service mix of accounting firms that influence firm productivity, this study considers the proportion of revenue from auditing services, the proportion of revenue from taxation services, and the proportion of management advisory and other services [1][2][3]. To account for the variations in service diversity among accounting firms that affect firm productivity, this study considers the degree to which total revenue is concentrated or dispersed among different service areas such as auditing services, taxation services, and management advisory, and other services [1][2]. Many public accounting firms have begun to focus on delegating low-level or routine work to support personnel and leveraging partner time to realize firm growth and maximize profits [5]. Therefore, to capture the variations in human resource utilization strategy across accounting firms, the leverage ratio defined as the ratio of non-partner employees to partners is considered [6].

Results of prior studies in human resource management literature suggest that higher training can have a positive impact on firm performance due to enhanced employee satisfaction and higher customer loyalty [7]. Specifically, in the public accounting profession, continuing professional education and training are likely to improve the expertise of professionals and heighten service quality. Thus, to account for the differences in the level of investment in human capital across accounting firms, this study examines the impact of the level of investment in employee training and education on firm productivity [8]. Furthermore, to explain the differences in employee satisfaction across accounting firms that may influence firm productivity, this study includes employee retention rate as a proxy for the level of employee satisfaction in accounting firms [9]. To explain the variations in the availability of financial resources across accounting firms that affect the productivity of accounting firms, this study uses two ratios separately: (i) the ratio of total liabilities to total equity to measure the status of firm's financial safety and (ii) the ratio of current liabilities to the quick assets to reflect the position of firm's liquidity [10][11].

The remainder of this paper is structured as follows. Section 2 presents a description of the research design including data, sample, variables, variable definitions, and estimation models. Section 3 provides empirical analysis including descriptive statistics and estimation results. Finally, Section 4 concludes.

\section{Research design}

\subsection{Data and sample}

This study employs a hand-collected unbalanced panel of data for Korean accounting firms from the year 1997 to 2018 to examine the relation between the output variable and input variables moderated by contextual variables. To this end, the annual reports of Korean accounting firms for the 1997-2002 period were collected from the Korean Institute of Certified Public Accountants and downloaded for the 2003-2018 period from the website of the Korean Financial Supervisory Service. In case accounting firms were newly established and started a business during a certain business period, those firms are not included in the sample of the corresponding business year. Thus, the number of accounting firms that are included in our sample each business year is 32 in 1997, 31 in 1998, 32 in 1999, 33 in 2000, 32 in 2001, 52 in 2002, 62 in 2003, 69 in 2004, 78 in 2005, 87 in 2006, 94 in 2007, 103 in 2008, 109 in 2009, 120 in 2010, 124 in 2011, 125 in 2012, 130 in 2013, 137 in 2014, 150 in 2015, 163 in 2016, 
171 in 2017 , and 180 in 2018, resulting in a total of 2,114 firm-year observations in the final sample.

\subsection{Output and input variables}

This study is to model the production function relating the output of each accounting firm in a specific business year as a function of its inputs such as labor and capital, and contextual variables [12]. The single output for each accounting firm is measured as annual total revenue (TREV) in deflated Korean won. Previous studies have included labor utilization and capital investment as inputs in the production function. To reflect the different roles of labor input in the production function, two different types of human resources separately are considered: (i) the number of equity partners and non-partner certified public accountants (PROF) and (ii) the number of other employees who are not certified public accountants and are regarded as supporting personnel (SUPP). In addition, to capture another capital input factor, the major form of capital investment for each accounting firm that comprises tangible assets, intangible assets, investment assets, and other noncurrent assets is considered [12]. Although previous studies did not consider any capital input variable in the production of accounting firms due to the lack of data on capital input [1][2][3], the book value of noncurrent assets (NCA) in deflated Korean won at the end of each business year is included. All of the output and input measures (TREV, PROF, SUPP, NCA) were transformed via the natural logarithm function (lnTREV, lnPROF, $\operatorname{lnSUPP}, \operatorname{lnNCA}$ ).

\subsection{Contextual variables and control variables}

This study also considers contextual variables including service mix, service diversity, leveraging of partner time, employee education and training, employee satisfaction, and financial resources. To capture the differences in the service mix of accounting firms, the following variables are considered: (i) the percentage of revenue from auditing services (AUDP), (ii) the percentage of revenue from taxation services (TAXP), and (iii) the percentage of management advisory and other services (MASP). As AUDP, TAXP, and MASP add up to $100 \%$, the percentage of revenue from taxation services (TAXP) and the percentage of revenue from management advisory and other services (MASP) are two variables constructed to represent the service mix [1].

To account for the variations in service diversity among accounting firms, this study considers the degree to which accounting firm total revenue is concentrated or dispersed among three service areas defined as auditing services, taxation services, and management advisory and other services. The degree of service diversification with the Herfindahl index of dispersion (SDIV) is measured as 1- (AUDP/100)2+(TAXP/100)2+(MASP/100)2[6]. The SDIV value equal to 0 would indicate that an accounting firm's services are concentrated in one area, whereas the SDIV value approaching 1 would indicate that an accounting firm's services are broadly dispersed among all service areas [6]. The higher the SDIV, the higher is the degree of service diversification, and the existence of scope economies is predicted to have a positive coefficient estimate for the variable SDIV.

To capture the variations in human resource utilization strategy among accounting firms, this study focuses on the degree to which non-partner employees are present to leverage the knowledge and skills of equity partners [6]. This variable of the leveraging of partner time (PLEV) is operationalized as the ratio of non-partner employees to partners [13]. To account for the differences in the level of investment in developing human capital across accounting firms, this study includes the variable TCOST, constructed to measure training costs per 
employee in deflated Korean won [5][7]. Results of prior studies in human capital management suggest that higher employee training can have a positive influence on firm performance due to enhanced employee satisfaction and higher customer loyalty [14]. Specifically, in the public accounting profession, continuing professional education and training are likely to improve the expertise of professionals and heighten service quality [7]. In turn, the higher average training costs per employee are likely to have a positive impact on the relation between the output variable and the input variables in the production function. Furthermore, to explain the differences in the level of employee satisfaction across accounting firms that may influence the relation between the output variable and input variables, employee retention rate (EMPRE) expressed in percentage terms is included. In general, when employees are more satisfied in an organization, they are likely to produce a better product or deliver better customer service which, in turn, leads to a higher level of repeat sales and higher market share along with higher customer loyalty [15]. Finally, employee satisfaction is likely to be more positively associated with firm performance [9]. Therefore, it is expected that the level of employee satisfaction will have a positive impact on the relation between the input variables and the output variable in the production function in the accounting industry.

This study also considers the variations in the availability of financial resources across accounting firms to examine the effect of financial capital on the productivity of accounting firms [10][11]. This study includes two variables, the debt-to-equity ratio (TLEQ) and the reciprocal of quick ratio (CLQA) to investigate their impact on firm productivity. The debt-toequity ratio (TLEQ) is measured by dividing total liabilities by total equity into percentage terms, and the reciprocal of the quick ratio (CLQA) is measured as current liabilities divided by quick assets into percentage terms [10][11].

To examine the productivity change over time, this study includes the variable LAPSE that denotes the number of years passed since the start of the sample period, defined as year-1996. To control for year fixed effects, 21 indicator variables for each of the business years are included for the 1998-2018 period such as D1998, D1999, D2000, D2001, D2002, D2003, D2004, D2005, D2006, D2007, D2008, D2009, D2010, D2011, D2012, D2013, D2014, D2015, D2016, D2017, and D2018.

\subsection{Variable definitions}

The definitions of the variables used in this study are summarized in [Table 1].

Table 1. Definition of the variables

\begin{tabular}{|c|c|}
\hline Variable & Definition \\
\hline $\mathrm{N}$ & Number of firm-year observations \\
\hline TREV & Total revenue deflated to the year 2018, expressed in million Korean won \\
\hline lnTREV & Natural logarithm of total revenue deflated to the year 2018 (TREV defined above) \\
\hline PART & Number of equity partners \\
\hline CPA & Number of certified public accountants who are not partners \\
\hline PROF & Number of professionals defined as the sum of PART and CPA \\
\hline lnPROF & Number of supporting personnel who are not certified, public accountants \\
\hline SUPP & Natural logarithm of the number of supporting personnel (SUPP defined above) \\
\hline lnSUPP & The total number of employees is defined as the sum of PART, CPA, and SUPP \\
\hline EMP &
\end{tabular}




\begin{tabular}{|c|c|}
\hline NCA & Noncurrent assets deflated to the year 2018, expressed in million Korean won \\
\hline lnNCA & Natural logarithm of the book value of non-current assets (NCA defined above) \\
\hline AUDP & $\begin{array}{r}\text { Percentage of revenue from auditing services } \\
\hline \text { TAXP }\end{array}$ \\
\hline MASP & $\begin{array}{r}\text { Percentage of revenue from taxation services } \\
\hline \text { SDIV }\end{array}$ \\
\hline PLEV & $\begin{array}{r}\text { Service diversification measured by the Herfindahl index, } \\
\text { calculated as 1- (AUDP/100) })^{2}+(\text { TAXP/100) }\end{array}$ \\
\hline TCOST & Training cost per employee deflated to the year 2018, expressed in million Korean won \\
\hline EMPRE & Employee retention rate, expressed in percentage terms \\
\hline TLEQ & The ratio of total liabilities to total equity, expressed in percentage terms \\
\hline CLQA & The ratio of current liabilities to quick assets expressed in percentage terms \\
\hline LAPSE & Number of years passed since the start of the sample period, defined as year-1996 \\
\hline DYEAR & Indicator variable for each year in the sample period (e.g., D1998 D2018) \\
\hline
\end{tabular}

\subsection{Estimation models}

In order to represent the technological relationship between the amounts of three inputs (PROF and SUPP for labor, NCA for physical capital) and the amount of output (TREV) that can be produced by those inputs, a Cobb-Douglas production function is specified as follows [2][3]:

$$
T R E V=e^{\alpha_{0}} \times P R O F^{\alpha_{1}} \times S U P P^{\alpha_{2}} \times N C A^{\alpha_{3}} \times e^{\theta}
$$

where,

$$
\begin{array}{r}
\theta=\beta_{1} \times T A X P+\beta_{2} \times M A S P+\beta_{3} \times S D I V+\beta_{4} \times P L E V+\beta_{5} \times T C O S T+\beta_{6} \times E M P R E+ \\
\beta_{7} \times T L E Q+\beta_{8} \times C L Q A
\end{array}
$$

Taking logarithm on both sides of equation (1) and substituting equation (2) for $\theta$, the following log-linear estimation model is obtained [2][3]:

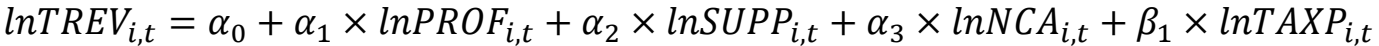

$$
\begin{aligned}
& +\beta_{2} \times M_{A S P_{i, t}}+\beta_{3} \times S D I V_{i, t}+\beta_{4} \times P L E V_{i, t}+\beta_{5} \times \operatorname{TCOST}_{i, t}+ \\
& \beta_{6} \times E M P R E_{i, t}+\beta_{7} \times T L E Q_{i, t}+\beta_{8} \times C L Q A_{i, t}+\varepsilon_{i, t}
\end{aligned}
$$

To control for year fixed effects, 21 indicator variables (D1998 D2018) are added to equation (3) and have the following estimation model:

$$
\begin{aligned}
& \operatorname{lnTREV} V_{i, t}=\alpha_{0}+\alpha_{1} \times \operatorname{lnPROF_{i,t}}+\alpha_{2} \times \operatorname{lnSUPP_{i,t}}+\alpha_{3} \times \ln N C A_{i, t}+\beta_{1} \times \ln T A X P_{i, t} \\
& +\beta_{2} \times \text { MASP }_{\mathrm{i}, \mathrm{t}}+\beta_{3} \times \mathrm{SDIV}_{\mathrm{i}, \mathrm{t}}+\beta_{4} \times \mathrm{PLEV}_{\mathrm{i}, \mathrm{t}}+\beta_{5} \times \mathrm{TCOST}_{\mathrm{i}, \mathrm{t}} \\
& +\beta_{6} \times \mathrm{EMPRE}_{\mathrm{i}, \mathrm{t}}+\beta_{7} \times \mathrm{TLEQ}_{\mathrm{i}, \mathrm{t}}+\beta_{8} \times \mathrm{CLQA}_{\mathrm{i}, \mathrm{t}}+\varphi_{1} \times \mathrm{D} 1998_{\mathrm{t}} \\
& +\varphi_{2} \times \mathrm{D} 1999_{\mathrm{t}}+\varphi_{3} \times \mathrm{D} 2000_{\mathrm{t}}+\varphi_{4} \times \mathrm{D} 2001_{\mathrm{t}}+\varphi_{5} \times \mathrm{D} 2002_{\mathrm{t}} \\
& +\varphi_{6} \times \mathrm{D} 2003_{\mathrm{t}}+\varphi_{7} \times \mathrm{D} 2004_{\mathrm{t}}+\varphi_{8} \times \mathrm{D} 2005_{\mathrm{t}}+\varphi_{9} \times \mathrm{D} 2006_{\mathrm{t}} \\
& +\varphi_{10} \times \mathrm{D} 2007_{\mathrm{t}}+\varphi_{11} \times \mathrm{D} 2008_{\mathrm{t}} \mathrm{D} 2008 \mathrm{t}+\varphi_{12} \times \mathrm{D} 2009_{\mathrm{t}}+\varphi_{13} \times \mathrm{D} 2010_{\mathrm{t}} \\
& +\varphi_{14} \times \mathrm{D} 2011_{\mathrm{t}}+\varphi_{15} \times \mathrm{D} 2012_{\mathrm{t}}+\varphi_{16} \times \mathrm{D} 2013_{\mathrm{t}}+\varphi_{17} \times \mathrm{D} 2014_{\mathrm{t}} \\
& +\varphi_{18} \times \mathrm{D} 2015_{\mathrm{t}}+\varphi_{19} \times \mathrm{D} 2016_{\mathrm{t}}+\varphi_{20} \times \mathrm{D} 2017_{\mathrm{t}}+\varphi_{21} \times \mathrm{D} 2018_{\mathrm{t}} \\
& +\varepsilon_{\mathrm{i}, \mathrm{t}}
\end{aligned}
$$


To estimate the trend of productivity change over time for the whole sample period, the variable LAPSE is added to equation (3) and the following estimation model is obtained:

$$
\begin{aligned}
\operatorname{lnTREV}_{i, t}= & \alpha_{0}+\alpha_{1} \times \operatorname{lnPROF} F_{i, t}+\alpha_{2} \times \operatorname{lnSUPP} P_{i, t}+\alpha_{3} \times \operatorname{lnNCA} A_{i, t}+\beta_{1} \times \operatorname{lnTAXP} P_{i, t} \\
& +\beta_{2} \times \mathrm{MASP}_{\mathrm{i}, \mathrm{t}}+\beta_{3} \times \mathrm{SDIV}_{\mathrm{i}, \mathrm{t}}+\beta_{4} \times \mathrm{PLEV}_{\mathrm{i}, \mathrm{t}}+\beta_{5} \times \mathrm{TCOST}_{\mathrm{i}, \mathrm{t}} \\
& +\beta_{6} \times \mathrm{EMPRE}_{\mathrm{i}, \mathrm{t}}+\beta_{7} \times \mathrm{TLEQ}_{\mathrm{i}, \mathrm{t}}+\beta_{8} \times \mathrm{CLQA}_{\mathrm{i}, \mathrm{t}}+\delta_{1} \times \mathrm{LASPE}_{\mathrm{t}}+\varepsilon_{\mathrm{i}, \mathrm{t}}
\end{aligned}
$$

\section{Empirical analysis}

\subsection{Descriptive statistics}

[Table 2] presents the summary statistics on output, inputs, and contextual variables used in this study for the entire sample period.

Table 2. Descriptive statistics for pooled data

\begin{tabular}{|c|c|c|c|c|c|c|}
\hline Variable & $\mathrm{N}$ & Mean & $\mathrm{SD}$ & $\mathrm{Q} 1$ & Median & Q3 \\
\hline TREV & 2,114 & $18,235.72$ & $56,413.87$ & $4,022.55$ & $6,396.35$ & $9,662.23$ \\
\hline PART & 2,114 & 18.17 & 22.92 & 8.00 & 12.00 & 19.00 \\
\hline CPA & 2,114 & 59.68 & 236.24 & 4.00 & 9.00 & 20.00 \\
\hline PROF & 2,114 & 77.85 & 253.52 & 14.00 & 22.00 & 35.00 \\
\hline SUPP & 2,114 & 63.77 & 117.27 & 19.00 & 37.50 & 60.00 \\
\hline EMP & 2,114 & 141.62 & 363.62 & 37.00 & 62.00 & 92.00 \\
\hline NCA & 2,114 & $2,070.64$ & $4,511.94$ & 608.89 & $1,018.59$ & $1,630.98$ \\
\hline AUDP & 2,114 & 32.21 & 14.44 & 22.15 & 30.63 & 40.12 \\
\hline TAXP & 2,114 & 20.71 & 12.10 & 13.27 & 18.56 & 25.55 \\
\hline MASP & 2,114 & 47.08 & 16.09 & 37.26 & 47.74 & 56.64 \\
\hline SDIV & 2,114 & 0.5703 & 0.0924 & 0.5469 & 0.5998 & 0.6283 \\
\hline PLEV & 2,114 & 5.1353 & 4.1775 & 2.5714 & 4.0000 & 5.9063 \\
\hline TCOST & 2,114 & 0.4600 & 0.5976 & 0.1366 & 0.3045 & 0.5571 \\
\hline EMPRE & 2,114 & 84.22 & 16.61 & 77.78 & 88.26 & 95.83 \\
\hline TLEQ & 2,114 & 147.05 & 114.47 & 76.20 & 121.07 & 189.93 \\
\hline CLQA & 2,114 & 68.15 & 30.78 & 50.31 & 65.93 & 82.73 \\
\hline
\end{tabular}

The mean and median annual total revenue (TREV) is 18,235.72 million KRW and 6,396.35 million KRW, respectively. The mean and median of the total number of employees are 141.62 and 62.00, respectively. The distribution of all size-related output and input variables (TREV, PART, CPA, PROF, SUPP, EMP, NCA) is skewed to the right because the mean value of each variable is much larger than its median value, which is consistent with the results of prior studies [1][2][3]. On average, the proportion of auditing revenue (AUDP) is $32.21 \%$, the proportion of taxation revenue (TAXP) is $20.71 \%$, and the proportion of management advisory and other revenue (MASP) is $47.08 \%$. The mean and median of leveraging of partner time (PLEV) is 5.1353 and 4.000 , respectively, indicating that there are 4 or 5 non-partner employees per partner in accounting firms. On average, training costs per employee (TCOST) are 0.46 million KRW, and the employee retention rate (EMPRE) is $84.22 \%$, which implies an average employee turnover rate of $15.78 \%$. On average, the ratio of total liabilities to total equity is $147.05 \%$ and the ratio of current liabilities to quick assets is $68.15 \%$. 


\subsection{Estimation results}

For the pooled data the estimation models expressed in equations (3), (4), and (5) are run and the estimation results are reported in [Table 3].

Table 3. Estimation results for pooled data

\begin{tabular}{|c|c|c|c|c|c|}
\hline & & & Equation (3) & Equation (4) & Equation (5) \\
\hline Variable & Parameter & $\begin{array}{l}\text { Predicted } \\
\text { Sign }\end{array}$ & $\begin{array}{c}\text { Parameter Estimate } \\
\text { (t-value) }\end{array}$ & $\begin{array}{c}\text { Parameter Estimate } \\
\text { (t-value) }\end{array}$ & $\begin{array}{c}\text { Parameter Estimate } \\
\text { (t-value) }\end{array}$ \\
\hline Intercept & $\alpha_{0}$ & $?$ & $\begin{array}{c}3.7971 * * * \\
(42.86)\end{array}$ & $\begin{array}{c}3.4724 * * * \\
(35.23)\end{array}$ & $\begin{array}{c}3.6448 * * * \\
(40.68)\end{array}$ \\
\hline $\ln \mathrm{PROF}$ & $\alpha_{1}$ & + & $\begin{array}{l}0.7080 * * * \\
(59.39)\end{array}$ & $\begin{array}{c}0.6939 * * * \\
(58.35)\end{array}$ & $\begin{array}{c}0.6876^{* * * *} \\
(57.03)\end{array}$ \\
\hline $\operatorname{lnSUPP}$ & $\alpha_{2}$ & + & $\begin{array}{c}0.0474 * * * \\
(13.97)\end{array}$ & $\begin{array}{c}0.0475 * * * \\
(14.33)\end{array}$ & $\begin{array}{c}0.0474 * * * \\
(14.16)\end{array}$ \\
\hline $\operatorname{lnNCA}$ & $\alpha_{3}$ & + & $\begin{array}{l}0.2822 * * * \\
(22.25)\end{array}$ & $\begin{array}{l}0.2901 * * * \\
(23.37)\end{array}$ & $\begin{array}{c}0.2943 * * * \\
(23.34)\end{array}$ \\
\hline TAXP & $\beta_{1}$ & $?$ & $\begin{array}{c}0.0126 * * * \\
(18.87)\end{array}$ & $\begin{array}{c}0.0115 * * * \\
(17.23)\end{array}$ & $\begin{array}{c}0.0113 * * * \\
(16.77)\end{array}$ \\
\hline MASP & $\beta_{2}$ & $?$ & $\begin{array}{c}0.0102 * * * \\
(20.11)\end{array}$ & $\begin{array}{c}0.0092 * * * \\
(17.66)\end{array}$ & $\begin{array}{c}0.0090 * * * \\
(17.18)\end{array}$ \\
\hline SDIV & $\beta_{3}$ & $?$ & $\begin{array}{c}0.4066^{* * * *} \\
(5.33)\end{array}$ & $\begin{array}{c}0.2903 * * * \\
(3.83)\end{array}$ & $\begin{array}{c}0.2836^{* * * *} \\
(3.69)\end{array}$ \\
\hline PLEV & $\beta_{4}$ & + & $\begin{array}{c}0.0054 * * * \\
(2.79)\end{array}$ & $\begin{array}{c}0.0085 * * * \\
(4.44)\end{array}$ & $\begin{array}{c}0.0083 * * * \\
(4.28)\end{array}$ \\
\hline TCOST & $\beta_{5}$ & + & $\begin{array}{c}0.0462 * * * \\
(4.20)\end{array}$ & $\begin{array}{c}0.0554 * * * \\
(5.06)\end{array}$ & $\begin{array}{c}0.0613 * * * \\
(5.56)\end{array}$ \\
\hline EMPRE & $\beta_{6}$ & + & $\begin{array}{c}0.0010 * * * \\
(2.65)\end{array}$ & $\begin{array}{c}0.0012 * * * \\
(3.14)\end{array}$ & $\begin{array}{c}0.0010 * * \\
(2.56)\end{array}$ \\
\hline TLEQ & $\beta_{7}$ & $?$ & $\begin{array}{c}0.0004 * * * \\
(7.00)\end{array}$ & $\begin{array}{c}0.0005^{* * * *} \\
(7.30)\end{array}$ & $\begin{array}{c}0.0005^{* * * *} \\
(7.84)\end{array}$ \\
\hline CLQA & $\beta_{8}$ & $?$ & $\begin{array}{c}-0.0027 * * * \\
(-11.51) \\
\end{array}$ & $\begin{array}{c}-0.0026 * * * \\
(-11.63)\end{array}$ & $\begin{array}{c}-0.0026^{* * *} \\
(-11.45)\end{array}$ \\
\hline LAPSE & $\delta_{1}$ & $?$ & Excluded & Excluded & $\begin{array}{c}0.0093 * * * \\
(7.70)\end{array}$ \\
\hline DYEAR & $\varphi_{1} \sim \varphi_{21}$ & $?$ & Excluded & Included & Excluded \\
\hline \multicolumn{3}{|c|}{$\alpha_{1}+\alpha_{2}+\alpha_{3}$} & 1.0376 & 1.0315 & 1.0293 \\
\hline \multicolumn{3}{|c|}{ Significance level: $\alpha_{1}+\alpha_{2}+\alpha_{3}=1$} & 0.0001 & 0.0010 & 0.0024 \\
\hline \multicolumn{3}{|c|}{ Significance level: $\beta_{1}=\beta_{2}$} & $<.0001$ & $<.0001$ & $<.0001$ \\
\hline \multicolumn{3}{|c|}{ F-value } & $2,442.78$ & 898.08 & $2,306.16$ \\
\hline \multicolumn{3}{|c|}{ Adjusted R-square } & 0.9271 & 0.9314 & 0.9290 \\
\hline \multicolumn{3}{|c|}{ Number of observations } & 2,114 & 2,114 & 2,114 \\
\hline
\end{tabular}

** indicates statistically significant at the $5 \%$ level

*** indicates statistically significant at the $1 \%$ level for two-sided hypothesis tests.

First, the coefficient estimates for the three input resources (lnPROF, $\operatorname{lnSUPP}, \operatorname{lnNCA}$ ) are found to be significantly and positively associated with total revenue in all estimation models. To check whether the economies of scale exist in the Korean accounting industry, an F test is conducted for constant returns to scale, that is, the null hypothesis: $\alpha_{1}+\alpha_{2}+\alpha_{3}=1$. The results of the $\mathrm{F}$ test reject the null hypothesis in favor of the alternative hypothesis with $\mathrm{p}$-value $=0.0001$ for Equation (3), p-value $=0.0010$ for Equation (4), and p-value $=0.0024$ for Equation (5), supporting the increasing returns to scale in the Korean accounting industry, consistent with the results of prior studies [2][3]. 
Second, both the coefficient estimates of TAXP and MASP are found to be positive and statistically significant, and the coefficient estimate of TAXP is found to be significantly greater than that of MASP. These results suggest the following implications: (i) both taxation services and management advisory $\&$ other services are productive in generating total revenue, (ii) taxation services exhibit a higher productivity than management advisory \& other services, and (ii) accounting firms concentrating on auditing services are likely to be less productive in revenue generation.

Third, the coefficient estimate for SDIV is positive and statistically significant ( $\mathrm{p}$-value < 0.0001 in all estimation models), suggesting that accounting firms are better off increasing the degree of service diversification among different service areas. Thus, the data support the existence of economies of scope in the Korean accounting industry in all estimation models, expressed in Equations (3), (4), and (5).

Fourth, the coefficient estimates for each of PLEV, TCOST, and EMPRE is positive and statistically significant, suggesting that accounting firms with the higher leveraging of partner time, the higher level of investment in employee training and education, and the higher level of employee satisfaction are more productive in generating total revenue.

Fifth, the coefficient estimate of TLEQ is positive and statistically significant, while the coefficient estimate of CLQA is negative and statistically significant. This result suggests that accounting firms with a higher debt-to-equity ratio and the higher quick ratio are more productive in revenue generation.

Lastly, the coefficient estimates for LAPSE in the estimation model expressed in Equation (5) is positive and statistically significant (coefficient $=0.0093$, t-value $=7.70$, $p$-value $<0.0001$ ), suggesting that the productivity level of the accounting industry in South Korea is improving over time even after deflating the total revenue variable [1].

\section{Conclusion}

Using an unbalanced panel of data for Korean accounting firms from the year 1997 to 2018, this study has examined the production function relating the output of accounting firms as a function of its input resources such as labor and capital, along with contextual variables that moderate the relation between the output variable and the input resources variables. The main findings from this study can be summarized as follows. First, it is documented that the increasing returns to scale exits in the Korean accounting industry, consistent with the results of prior studies [2][3]. Second, it is shown that accounting firms are better off increasing the degree of service diversification among different service areas, supporting the existence of economies of scope in the Korean accounting industry. Third, it is demonstrated that both taxation services and management advisory \& other services are productive in generating total revenue, and taxation services exhibit a higher productivity than management advisory \& other services. However, accounting firms concentrating on auditing services are found to be less productive in revenue generation. Fourth, the contextual variables such as the degree of leveraging of partner time, the level of investment in employee training, the level of employee retention rate, the debt-to-equity ratio, and the quick ratio are found to be positively associated with firm productivity. Lastly, the productivity level of the accounting industry in South Korea was found to improve continuously over the period 1997 to 2018.

This study sheds light on the major firm characteristics that affect the productivity in the Korean accounting industry that plays a pivotal role as a watchdog in the capital markets. Understanding the factors moderating production function in the accounting industry is expected to provide fruitful insights for improving the productivity of professional service firms. 


\section{References}

[1] R. D. Banker, H. Chang, and R. Cunningham, "The public accounting industry production function," Journal of Accounting and Economics, vol.35, pp.255-281, (2003)

[2] S. -Y. Lee, "An analysis of production function of Korean accounting Firms," Advanced Science Letters, vol.22, no.11, pp.3598-3602, (2016)

[3] S. -Y. Lee and H. Kim, "An analysis of the relation between inputs and total revenues in Korean accounting firms," Korean Accounting Review, vol.26, no.4, pp.83-107, (2001)

[4] S. -Y. Lee, "Analysis of the global steel industry production function," Asia-pacific Journal of Multimedia Services Convergent with Art, Humanities, and Sociology, vol.8, no.1, pp.91-100, (2018)

[5] Y. Y. Kor and H. Leblebici, "How do interdependencies among human-capital deployment, development, and diversification strategies affect firms' financial performance?” Strategic Management Journal, vol.26, pp.967985, (2005)

[6] R. Eckardt and B. C. Skaggs, "Service diversification and growth of professional service firms," Long Range Planning, vol.51, no.1, pp.111-126, (2018)

[7] Y.-S. Chen, B.-G. Chang, and C.-C. Lee, "The association between continuing professional education and financial performance of public accounting firms," The International Journal of Human Resource Management, vol.19, no.9, pp.1720-1737, (2008)

[8] L. Kolvereid and B. W. Amo, "Growth intention and growth in small accounting firms," Administrative Sciences, vol.9, no.2, pp.36-46, (2019)

[9] J. I. Hancock, D. G. Allen, F. A. Bosco, K. R. McDaniel, and C. A. Pierce, "Meta-analytic review of employee turnover as a predictor of firm performance," Journal of Management, vol.39, no.3, pp.573-603, (2013)

[10] S.-Y. Lee, "The impact of non-audit services on accounting firm productivity," International Journal of u- and e-Service, Science and Technology, vol.8, no.10, pp.41-52, (2015)

[11] S.-Y. Lee, "Determinants of audit revenues of accounting firms," International Journal of u- and e-Service, Science and Technology, vol.8, no.9, pp.291-302, (2015)

[12] R. D. Banker, S.-Y. Lee, G. Potter, and D. Srinivasan, "The impact of supervisory monitoring on high-end retail sales productivity,” Annals of Operations Research, vol.173, pp.25-37, (2010)

[13] K. Amin, R. D. Banker, and E. Whang, "A tale of two professions: The impact of SOX and the global economic crisis on public accounting and law firms' performance," Journal of Accounting, Auditing, and Finance, (2021), doi.org/10.1177/0148558X211019691

[14] T. Garavan, A. McCarthy, Y. Lai, K. Murphy, M. Sheehan, and R. Carbery, "Training and organizational performance: A meta-analysis of temporal," Institutional, and Organizational Context Moderators, Human Resource Management Journal, vol.31, no.1, pp.93-119, (2021)

[15] S. R. Kessler, L. Lucianetti, S. Pindek, Z. Zhu, and P. E. Spector, "Job satisfaction and firm performance: Can employees' job satisfaction change the trajectory of a firm's performance?" Journal of Applied Social Psychology, vol.50, no.10, pp.563-572, (2020) 
An Exploratory Study of Factors Affecting Production Function in the Accounting Industry

This page is empty by intention. 